Kolaborasi : Jurnal Administrasi Publik, April 2020 Volume 6 Nomor 1

\title{
PELAKSANAAN PENGAWASAN BADAN URUSAN LOGISTIK (BULOG) DALAM PENGENDALIAN PANGAN DI KABUPATEN BONE
}

\author{
Ical Haedar ${ }^{1}$, Alyas ${ }^{2}$, Abdul Kadir Adys ${ }^{3}$ \\ ${ }^{1}$ Mahasiswa Program Studi Ilmu Administrasi Negara Fisip Unismuh \\ ${ }^{2}$ Dosen Program Studi Ilmu Administrasi Negara Fisip Unismuh \\ ${ }^{3}$ Dosen Program Studi Ilmu Administrasi Negara Fisip Unismuh
}

\begin{abstract}
This study aimed to determine the implementation of supervision of the Logistics Affairs Agency; Badan Urusan Logistik (BULOG) in food control. This study used qualitative research a type of phenomenology with data collection methods were interviews and other secondary data support. The results of this study showed that the implementation of Bulog supervision in Bone Regency included monitoring, examination, assessment, interviewing, observation, calculation, analysis and reporting. Monitoring of the Bulog's calculations in Bone Regency had been done well by the Internal Supervisory System, in terms of reporting including matched monthly reports after being authorized by the Wajo sub-divorce then reported to the Center were made. However, in terms of food analysis, Bulog did not comply with the warehousing system, such as the regulation of water content of rice that did not meet the standards of warehouse entry.
\end{abstract}

Keywords: Supervision, Logistics Agency

\begin{abstract}
ABSTRAK
Penelitian ini bertujuan untuk mengetahui pelaksanaan pengawasan Badan Urusan Logistik (BULOG) dalam pengendalian pangan. Penelitian kualitatif ini menggunakan tipe fenomenologi dengan metode pengumpulan data yakni wawancara serta dukungan data sekunder lainnya. Hasil penelitian ini ditemukan bahwa pelaksanaan pengawasan Bulog di Kabupaten Bone meliputi pemantauan, pemeriksaan, penilaian, wawancara, pengamatan, perhitungan, analisis dan pelaporan. Pemantauan hingga perhitungan pihak Bulog di Kabupaten Bone telah dilakukan dengan baik oleh Sistem Pengawas Internal, dalam hal pelaporan meliputi laporan bulanan yang dicocokkan setelah mendapat wewenang dari sub divre Wajo kemudian dibuatkan laporan ke Pusat. Namun dalam hal analisis pangan pihak Bulog kurang mematuhi sistem pergudangan seperti aturan kadar air beras yang tidak memenuhi standar masuk gudang.
\end{abstract}

Kata Kunci : Pengawasan, Badan Urusan Logistik

Website : http://journal.unismuh.ac.id/index.php/kolaborasi 
Kolaborasi : Jurnal Administrasi Publik, April 2020 Volume 6 Nomor 1

\section{PENDAHULUAN}

Bahan pangan menjadi hal yang utama dalam rangka memenuhi kebutuhan pokok manusia untuk melangsungkan hidup. Ketersediaan pangan dalam kualitas yang baik dan jumlah yang cukup (kuantitas) akan memberikan dampak yang baik terhadap beberapa aspek di antaranya ekonomi, sosial, tenaga kerja, lingkungan hidup, dan politik.

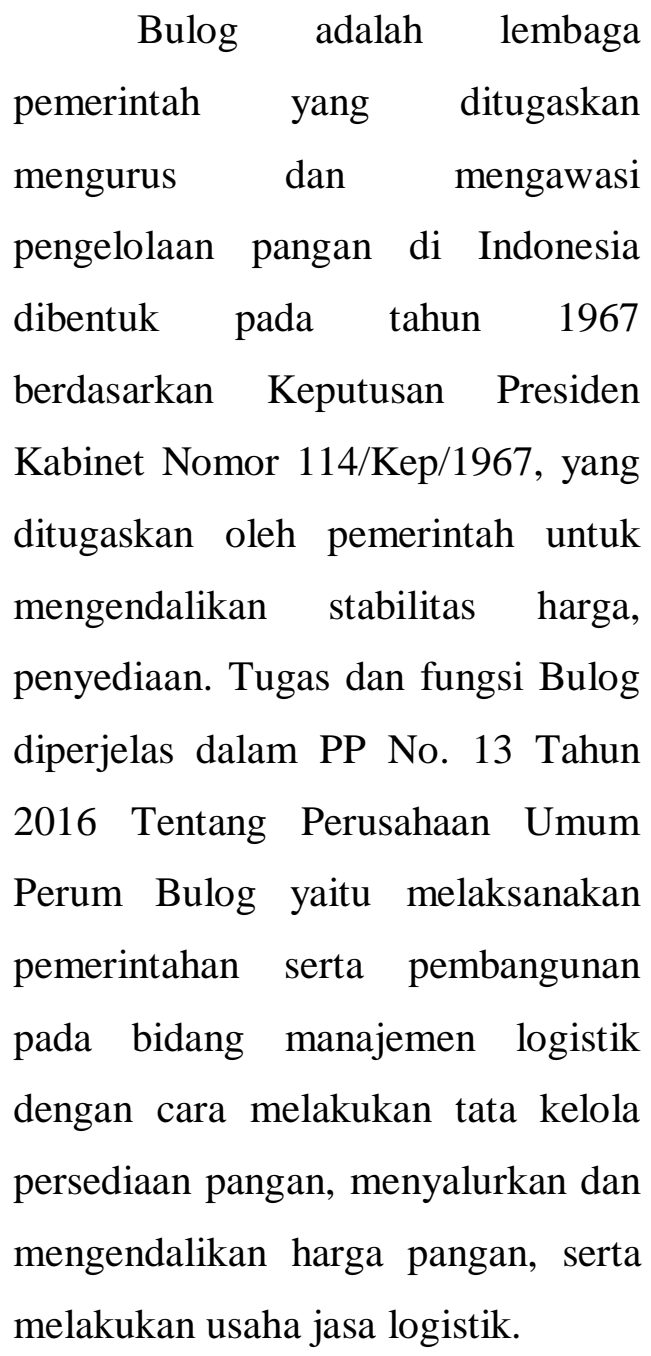

Pengawasan adalah suatu proses untuk menetapkan pekerjaan apa yang dijalankan, dilaksanakan, atau diselenggarakan itu serta apa yang dikehendaki, direncanakan atau diperhatikan. Di dalam pemahaman ini terkandung makna sinkronisasi. Antar apa yang telah direncanakan, kemudian dilaksanakan dan akhirnya diarahkan agar tidak terjadi penyimpangan antara rencana dan pelaksanaannya Atmosudirdjo (Suriansyah, 2014:03)

Pengawasan adalah suatu proses untuk menetapkan suatu pekerjaan apa yang sudah dilaksanakan, menilainya dan mengoreksi jika perlu dengan maksud agar pelaksanaan pekerjaan sesuai dengan rencana semula $\mathrm{M}$. Manullang (Suriansyah 2014:03)

Pengawasan adalah proses pengamatan atas seluruh kegiatan organisasi untuk menjamin hendaknya semua pekerjaan yang sedang dilakukan beroperasi sesuai dengan rencana yang telah ditetapkan sebelumnya Siagian (Torang, 2013:176)

$\begin{array}{rlr}\text { pengawasan } & \text { sebagai } & \text { suatu } \\ \text { pekerjaan apa } & \text { yang } & \text { sudah }\end{array}$


Kolaborasi : Jurnal Administrasi Publik, April 2020 Volume 6 Nomor 1

dilaksanakan, menilainya dan bila perlu mengoreksi dengan maksud agar pelaksanaan pekerjaan selaras dengan rencana semula Manullang (Murwaningsih, $2013: 47$ )

$$
\text { Pengawasan manajemen }
$$

adalah usaha sistematik untuk menetapkan standar pelaksanaan dengan tujuan perencanaan merancang sistem informasi umpan balik membandingkan kegiatan nyata dengan standar yang telah ditentukan sebelumnya, menentukan dan mengukur kelengahankelengahan serta mengambil tindakan perbaikan yang diperlukan untuk menjamin semua sumber daya perusahaan digunakan dengan cara yang paling efektif dan efisien dalam pencapaian tujuan-tujuan perusahaan. Robert J. Mokler (Rahmawati 2007: 26)

Fungsi pengawasan adalah mempertebal rasa tanggung jawab terhadap pejabat yang diberikan tugas dan wewenang dalam pelaksanaan pekerjaan. Mendidik para pejabat supaya mereka melaksanakan pekerjaannya sesuai dengan prosedur yang telah ditentukan. Untuk mencegah terjadinya penyimpangan, kelalaian, dan kelemahan, agar tidak terjadi defisit yang tidak diinginkan. Untuk memperbaiki penyimpangan dan penyelewengan, agar pelaksanaan pekerjaan tidak mengalami kendala dan pemborosan-pemborosan. (Effendi 2015 : 232)

tujuan pengawasan adalah: Membandingkan kejadian-kejadian dengan pengawasan yang sebelumnya telah dibuat, mengadakan perbaikan yang perlu dilakukan apabila kejadian-kejadian dalam kenyataan terjadi penyimpangan dari pada rencanarencana. Winardi (Murwaningsih 2013: 49)

Dari pendapat di atas, Murwaningsih memberikan kesimpulan bahwa tujuan diadakannya pengawasan, antara lain: (1) Untuk mengetahui pelaksanaan rencana, Tujuan utama adanya pengawasan untuk mengevaluasi apakah pelaksanaan rencana sudah sesuai atau belum. Rencana yang dibuat organisasi tentunya sudah dibuat semaksimal mungkin untuk mencapainya. Pencapaian tujuan organisasi 
Kolaborasi : Jurnal Administrasi Publik, April 2020 Volume 6 Nomor 1

menggunakan tahapan-tahapan, baik tahapan pendek, menengah atau panjang. Semua tahapan yang direncanakan perlu diawasi hasilnya. Apabila hasilnya kurang maksimal, maka harus dicari solusi yang paling tepat, sehingga organisasi dapat berjalan dan berkembang dengan baik. (2) Untuk mengetahui kesulitan yang terjadi, Setiap aktifitas pasti ada resikonya, baik resiko yang positif maupun negatif. Kalau resiko yang positif pastilah tidak akan mengganggu jalannya organisasi. Kalau resiko yang positif pastilah tidak akan mengganggu jalannya organisasi. Akan tetapi resiko yang negatife seperti kesulitan-kesulitan yang dihadapi karyawan maupun para manajer dalam menjalankan tugasnya perlu segera diketahui dan dicarikan solusinya. Dengan adanya pengawasan, organisasi dapat mengetahui kesulitan-kesulitan tersebut. Apabila terjadi peristiwa demikian, organisasi dapat mencari permasalahan yang timbul kemudian mengidentifikasi permasalahn yang timbul serta mencari solusinya. (3) Untuk mengantisipasi hambatanhambatan, ada pepatah, mencegah lebih baik dari pada mengobati. Pepatah ini mengandung makna bahwa organisasi perlu pengadaan antisipasi terhadap gangguangangguan dalam mencapai tujuannya. Cara untuk mengatasi gangguan adalah dengan dilakukannya kegiatan pengawasan. Apabila dalam organisasi ada indikasi terjadinya hambatan, hasil pengawasan dapat segera ditindak lanjuti. (4) Untuk mencari solusi apabila ada hambatan, Pengawasan diberlakukan untuk mencari solusi apabila ada hambatan dalam pelaksanaan tugas. Tidak ada organisasi yang tidak mempunyai masalah. Setiap masalah yang muncul harus segera diselesaikan supaya tidak mengganggu jalannya organisasi. Pengawasan yang dilakukan oleh organisasi menjadi hal penting untuk mencari jalan keluar apabila ada permasalahan. tahapan-tahapan pengawasan yaitu Menetapkan standar artinya perencanaan merupakan rancangan untuk mengukur secara logis hal ini berarti bahwa dalam proses pengawasan yang utama adalah menentukan standar. Mengukur 
Kolaborasi : Jurnal Administrasi Publik, April 2020 Volume 6 Nomor 1

kinerja atau melakukan perbaikan yang menyesuaikan berdasar pada tolak ukur yang telah ditentukan sebelumnya. Memperbaiki penyimpangan, pengawasan akan kurang jika dilakukan proses perbaikan terhadap tindakan kekeliruan tersebut. Kadarman (Mukarom : 2015)

Sudah menjadi pendapat umum (public opinion) jenis apapun pekerjaan di dunia ini senantiasa memerlukan suatu teknik atau dengan kata lain cara yang tepat sehingga pekerjaan tersebut mampu diselesaikan dengan baik dan memberikan hasil yang sesuai dengan harapan yang diharapkan. Berikut ini adalah teknik - teknik pelaksanaan pengawasan yang dilakukan sebagaimana terdapat dalam (Makmur 2011: 193) yaitu (1) Teknik pemantauan dalam pengawasan ini sangat dibutuhkan semua lembaga agar program yang direncanakan dapat terlaksana dengan baik, (2) teknik pemeriksaan dalam pengawasan harus dapat memberikan suatu informasi atau keterangan yang jelas dengan mengandung kebenaran atau keterangan kebenaran yang jelas agar dapat pula memberikan keyakinan kepada semua pihak atas hasil pengawasan yang telah dilakukan, (3) teknik penilaian sebagai bagian dari pada pengawasan terhadap pelaksanaan sesuatu kegiatan tentunya harus dilakukan secara tepat, adil dan jujur dengan jiwa keutamaannya, (4) teknik wawancara di bidang pengawasan dalam rangka mendapatkan informasi sehingga pengawasan dapat menentukan suatu keyakinan kebenaran atau kebenaran dalam kesalahan, (5) teknik pengamatan dilakukan dalam pengawasan untuk menyesuaikan antara informasi dan kebenaran yang terjadi sesuai dengan yang diharapkan, proses pengamatan harus dilakukan dengan cermat, (6) teknik perhitungan sangat memegang penting dalam pengawasan karena salah satu teknik untuk menentukan dari pada hasil pengawasan, kekeliruan dalam perhitungan berarti kesalahan hasil dalam pengawasan, (7) teknik analisis dalam pengawasan Setiap data dan informasi yang diterima dari kegiatan pengawasan harus dilakukan analisis untuk 
Kolaborasi : Jurnal Administrasi Publik, April 2020 Volume 6 Nomor 1

menentukan kualitas hasil kerja yang dilakukan oleh unit kerja teknis sehingga dapat memberikan suatu kepastian, (8) teknik pelaporan dalam pengawasan kadang tidak informatif karena sulit dipahami oleh penerima laporan, olehnya itu seharusnya menciptakan suatu teknik yang tepat sehingga tidak mengalami kesulitan dalam memahaminya.

Kabupaten Bone adalah salah satu daerah yang meraih penghargaan dalam peningkatan swasembada pangan, penghargaan ini diberikan karena dinilai bone mampu meningkatkan pertumbuhan ekonomi di bidang pertanian dan peternakan. Hal ini ditandai dengan meningkatnya hasil produksi beras untuk tahun 2016 semakin meningkat dan memenuhi target yaitu 1,2 juta ton dalam satu tahun. Dengan adanya peningkatan pertumbuhan ekonomi yang mencapai 9,06 persen ini dapat menekan inflasi hingga 1,48 persen (Rakyatku.Com, $01 \quad$ November 2017). Disamping hal ini ternyata di lapangan banyak hal yang harus diperbaiki oleh perum BULOG, penyaluran raskin yang kurang layak dikonsumsi hal ini terbukti dari sampel yang dibawa oleh warga terlihat bentuk beras yang tidak normal, tidak lagi utuh dan sudah berubah warna. Hal tersebut menimbulkan ketidak percayaan masyarakat kepada Perum Bulog Kabupaten Bone sehingga raskin saat ini dialihkan ke dinas sosial. Permasalahan tersebut tentu akan berpengaruh pada pelaksanaan pengawasan yang dilakukan BULOG dalam menangani permasalahan pangan.

Beras raskin yang tidak layak konsumsi sebanyak 4,5 ton yang disalurkan di masyarakat adalah salah satu masalah kurang teratasinya kualitas pangan dan ketahanan pangan. Hal tersebut didapatkan langsung oleh peneliti dan ditandai dengan adanya keluhan masyarakat mengenai kualitas beras raskin yang pecah-pecah, tidak lagi utuh, dan berubah warna. Keluhan masyarakat mengenai raskin menyebabkan raskin saat ini dialihkan ke dinas sosial. Masalah tersebut tidak searah dengan prestasi yang dicapai oleh kabupaten bone yang berhasil memenuhi target produksi beras sebanyak 1,2 juta ton sehingga 
Kolaborasi : Jurnal Administrasi Publik, April 2020 Volume 6 Nomor 1

mendapatkan penghargaan dalam meningkatkan swasembada pangan.

Berkaitan dengan penjelasan di atas, maka penulis tertarik untuk mengetahui lebih jelas lagi terkait pelaksanaan pengawasan dari Bulog Bone merujuk pada keberhasilan Kabupaten Bone dalam meningkatkan produksi pangan yang mampu mengatasi permasalahan pangan sehingga tercipta ketahanan pangan yang baik. Terkhusus Bulog di Kabupaten Bone mengurus dan mengawasi komoditas beras, terigu, gula, dan minyak. Dengan adanya pelaksanaan fungsi pengawasan Bulog Bone terhadap keempat komoditas tersebut, maka akan memberikan pengaruh atas terciptanya ketahanan pangan yang baik. Jika ketahanan pangan teratasi dengan baik, maka akan menciptakan adanya pengendalian pangan yang baik pula.

Pengendalian adalah salah satu fungsi manajemen yang harus dijalankan dalam pengelola suatu organisasi yang berbentuk perusahaan. Penerapan pengendalian manajemen diperlukan untuk mengendalikan suatu aktivitas dalam perusahaan agar berlangsung sesuai dengan rencana dan tujuan yang telah ditetapkan. (Rober N. Anthony $2008: 8)$

Dinamika ketahanan pangan adalah salah satu indikator ekonomi makro yang penting bagi suatu negara. Negara dengan ketahanan pangan yang lemah sudah dapat dipastikan akan rawan gejolak ekonomi dan politik, sehingga pada akhirnya akan berpengaruh terhadap stabilitas ekonomi dan politik negara yang bersangkutan.

Ketahanan pangan mencakup dimensi yang luas, yaitu produksi, ketesediaan (stock), akses, distribusi, dan keamanan pangan. Untuk itu, dalam menilai kinerja ketahanan pangan, kelima dimensi tersebut mestinya dapat dikaji dinamikanya, seperti yang akan diuraikan berikut ini, sedangkan kedaulatan pangan mengacu pada kemandirian bangsa dalam memproduksi secara beragam, menyediakan (melayani), menjaga keamanan, mendistribusikan dan meningkatkan nilai tambah pangan, sehingga terakses oleh seluruh warga bangsa secara berkelanjutan, termasuk oleh generasi yang akan 
Kolaborasi : Jurnal Administrasi Publik, April 2020 Volume 6 Nomor 1

datang. (Wahyu, Setiawan 2017 : 111).

\section{METODE PENELITIAN}

Penelitian ini tergolong dalam jenis penelitian deskriptif kualitatif yaitu penulis terjun langsung mengadakan penelitian yang telah ditentukan dengan menggunakan metode kualitatif.

Tipe penelitian yang digunakan yaitu fenomenologi yakni suatu penelitian yang meliputi proses pengumpulan data dan penjelasan data secara kualitatif.

Wawancara, metode yang digunakan dengan cara melakukan Tanya jawab atau percakapan dengan informan untuk memperoleh data,baik dengan menggunakan daftar pertanyaan atau percakapan bebas yang berhubungan dengan rumusan masalah yang sebelumnya telah dirumuskan.

Sumber data utama dalam penelitian kualitatif adalah kata-kata dan tindakan, selebihnya adalah data tambahan seperti dokumen dan lainlain.dimana data hasil penelitian didapatkan melalui dua sumber data yaitu data primer dan data sekunder.
Data tersebut dianalisis secara deskriptif diinterpretasikan pada informan dengan melakukan wawancara kemudian mengecek kembali data tersebut untuk memahami secara mendalam serta teori-teori yang sesuai dengan data tersebut yang dikumpulkan agar dapat menghasilkan peneltian yang bermutu.

Informan penelitian adalah orang yang diminta untuk memberikan informasi oleh pewawancara. Informan adalah orang yang dianggap menguasai dan memahami data, informasi maupun fakta dari suatu objek penelitian. (Bungin : 2011)

Untuk menganalisis berbagai fenomena di lapangan, Menurut McDrury (Moleong : 2014), mengatakan bahwa analisis data yang digunakan dalam penelitian dapat dilakukan dengan menerapakan langkah-langkah yaitu Reduksi data (Data Reduction), Penyajian data (Data Display), Penarikan Kesimpulan (conclusion Drawing and Verification.

Keabsahan data dalam penelitian ini menggunakan triangu- 
Kolaborasi : Jurnal Administrasi Publik, April 2020 Volume 6 Nomor 1

lasi, (Sugiyono 2014), menjelaskan ada tiga macam triangulasi. Ketiga triangulasi tersebut yaitu sumber, pengumpulan data, dan waktu.

\section{HASIL DAN PEMBAHASAN}

Badan Urusan Logistik (Bulog)

Kabupaten Bone merupakan perusahaan umum yang terletak di Jalan Jendral Sudirman, yang didirikan sejak tahun 1988 yang merupakan Badan Usaha Milik Negara (BUMN) kemudian pembangunan Perum Bulog direhabilitasi pada tanggal 09 Desember 2011 dan diresmikan pada tanggal 16 Mei 2012 oleh kepala Perum Bulog Divisi Regional Sulawesi Selatan Barat yaitu Tommy S. Sikado.

\section{Badan Urusan Logistik (Bulog)} di Kabupaten Bone merupakan Sub Divisi Regional Wajo yang bertugas untuk memenuhi stok pangan dan menentukan stabilitas harga. (Bulog) Kabupaten Bone memiliki satu kantor untuk melakukan segala kegiatan operasional terkait kegiatankegiatan yang dilakukan oleh bulog dalam hal ini penyerapan, penyaluran, dan pengeluaran barang komersial seperti beras, gula, minyak dan terigu.

$$
\text { Pelaksanaan pengawasan }
$$

Bulog di Kabupaten Bone dalam mengendalikan pangan berdasar pada delapan teknik-teknik pelaksanaan pengawasan yaitu pemantauan, pemeriksaan, penilaian, wawancara, pengamatan, perhitungan, analisis, dan pelaporan. Berikut ini Adalah pembahasan secara rinci mengenai teknik pelaksanaan pengawasan tersebut diuraikan sebagai berikut :

Pemantauan adalah salah satu teknik pelaksanaan pengawasan yang dilakukan oleh badan urusan logistik (Bulog) untuk mengetahui program yang direncanakan oleh lembaga badan urusan logistik (Bulog) dapat diimplementasikan dengan baik. Dalam melakukan pemantauan badan urusan logistik (Bulog) di Kabupaten Bone diawasi langsung oleh Sistem Pengawas Internal (SPI). untuk melihat kondisi bahan pangan dan memastikan keamanan bahan pangan yang ada di setiap gudang. Keamanan bahan pangan yang ada di setiap gudang dapat dipastikan tingkat keamanannya setelah 
Kolaborasi : Jurnal Administrasi Publik, April 2020 Volume 6 Nomor 1

melakukan pemantauan. Perum Bulog di Kabupaten Bone tidak hanya dipantau oleh sistem pengawas internal di gudang dalam setiap bulan, akan tetapi para pegawai di Perum Bulog Kabupaten Bone juga melakukan pemantauan terhadap stabilitas harga pasar. pemantauan yang dilakukan oleh Pelaksana Gasar Perum Bulog Kabupaten Bone dimaksudkan untuk mengetahui keamanan harga bahan pangan dan untuk menstabilkan harga pasar sehingga dapat dipastikan tidak adanya penjual di pasar yang menaikkan harga tanpa sepengetahuan dari pihak pemantau dari Perum Bulog Kabupaten Bone. Adapun pemantauan pasar yang biasa dilakukan oleh petugas Gasar Perum Bulog Bone yaitu pasar Bajoe dan Palakka yang merupakan pusat pasar terbesar di kota watampone yang sangat ramai oleh pembeli. Selain hal tersebut Perum Bulog Kabupaten Bone juga melakukan pemantauan pada bidang komersil.

Namun dalam hal ini, Perum Bulog Kabupaten Bone dalam memberikan harga pemasaran di pasar kepada tokoh masyarakat yang menjual di pasar tidak jelas dalam memberikan harga bahan komersil sehingga membingungkan penjual di pasar untuk menentukan keuntungan yang didapatkannya setelah melakukan penjualan.

Pemeriksaan adalah teknik pelaksanaan pengawasan kedua setelah dilakukannya pemantauan. Pemeriksaan dilakukan untuk mendapatkan informasi yang jelas mengenai kesalahan yang ada selama melakukan pengawasan sehingga para pegawai yang ada di Perum Bulog Kabupaten Bone dapat melakukan evaluasi setelah mengetahui kesalahan yang didapatkan setelah dilakukannya pemeriksaan. Perum Bulog Kabupaten Bone tidak hanya diperiksa dari segi bahan pangan yang ada dalam gudang, namun pemeriksaan juga dilakukan dari segi administrasi.

Sistem pengawas internal (SPI) dan Kepala Kansilog Kabupaten Bone memegang peran utama dalam melakukan pemeriksaan secara rutin di dalam gudang untuk melihat cara para pegawai Perum Bulog dalam melakukan perawatan seperti 
Kolaborasi : Jurnal Administrasi Publik, April 2020 Volume 6 Nomor 1

penyemprotan hama. Hal tersebut dilakukan untuk memastikan kualitas bahan pangan yang ada dalam gudang masih terjaga dengan baik.

Berdasarkan pemeriksaan secara rutin yang dilakukan oleh sistem pengawas internal seharusnya tidak terdapat permasalahan mengenai kualitas pangan di Perum Bulog Kabupaten Bone, namun berdasarkan realita di lapangan masih terdapat permasalahan kurang terkendalinya kualitas pangan di Perum Bulog Kabupaten Bone. seperti masih di temukannya kualitas beras yang kurang layak konsumsi dan permasalahan Raskin yang mengeluhkan masyarakat. Hal tersebut membuktikan bahwa pemeriksaan yang dilakukan oleh Sistem Pengawas Internal (SPI) masih kurang maksimal, hal tersebut membuktikan adanya kesalahan yang direkayasa menjadi suatu kebenaran oleh sistem pengawas internal karena yang diperiksa terdapat ikatan yang akrab, maka pernyataan tersebut telah membenarkan teori teknikteknik pengawasan dari segi pemeriksaan.
Penilaian adalah salah satu bagian penting dari teknik - teknik pelaksanaan pengawasan yang dapat menentukan sejauh mana kinerja prestasi yang diraih oleh Perum Bulog Kabupaten Bone berdasarkan hasil kerja yang telah dilaksanakan oleh para pegawai. Penilaian di Perum Bulog Kabupaten Bone dilakukan oleh Sistem Pengawas Internal (SPI) Dan Kepala Kansilog Kabupaten Bone.

Penilaian oleh Sistem Pengawas Internal (SPI) untuk mengetahui terlaksananya program kerja di gudang dan untuk mengetahui tidak adanya penyimpangan dalam gudang. Kepala Kansilog Kabupaten Bone untuk memberikan penilaian yang efektif kepada seluruh pegawai di Perum Bulog Bone dalam melaksanakan program kerja dan mencapai target yang telah ditentukan oleh Perum Bulog Kabupaten Bone. . Selain penilaian yang dilakukan oleh kepala kansilog terdapat pula penilaian yang dilakukan oleh Kepala Gudang perum bulog Kabupaten Bone melakukan penilaian terhadap 
Kolaborasi : Jurnal Administrasi Publik, April 2020 Volume 6 Nomor 1

bawahannya di lingkup pergudangan dan melakukan penilaian terhadap beras mengenai layak tidaknya masuk ke gudang kemudian dilaporkan kepada kepala Kansilog Kabupaten Bone. Penilaian juga dilakukan oleh pegawai komersil yang menilai pencapaian target penjualan bahan pangan yang ada di gudang.

Wawancara adalah teknik terpenting dalam melaksanakan pengawasan, melalui wawancara maka pengawas lebih mudah mendapatkan data dan informasi. Wawancara digunakan oleh pengawas untuk mengetahui kesesuaian antara pernyataan yang diberikan dengan keadaan di lapangan. Kebenaran mengenai terlaksananya program kerja di Perum Bulog Kabupaten Bone dapat diketahui oleh pengawas melalui wawancara langsung dan sistem pengawasan tertentu untuk mengetahui terkendalinya program kerja dan stabilitas pangan di gudang. Beberapa hal yang biasanya diwawancarai oleh Sistem Pengawas Internal (SPI) seperti administrasi bahan pangan yang ada di gudang apakah sesuai dengan bahan pangan yang ada di gudang atau tidak, administrasi komersil mengenai bahan pangan yang tersimpan di gudang dengan yang terjual

Pengamatan adalah salah satu teknik pelaksanaan pengawasan yang dilakukan untuk mengetahui secermat mungkin antara pernyataan yang diberikan dengan keadaan yang sebenarnya baik pengamatan melalui bahan pangan yang ada di gudang maupun para pegawai yang terikat dalam Perum Bulog Kabupaten Bone. dalam hal ini pengawas tidak hanya melihat aturan yang ada namun lebih jeli dalam melihat pelaksanaan peraturan di lapangan. Pelaksanaan aturan di lapangan juga perlu dievaluasi oleh Sistem Pengawas Internal (SPI) karena jangan sampai ada aturan yang tidak efisien untuk diterapkan di lapangan. Hal tersebut biasa didapatkan oleh Sistem Pengawas Internal (SPI) apabila didapatkan aturan yang melenceng di Perum Bulog Kabupaten Bone.

Pengamatan di Perum Bulog Kabupaten Bone diterapkan dengan melihat secara langsung para 
Kolaborasi : Jurnal Administrasi Publik, April 2020 Volume 6 Nomor 1

pegawai bekerja sesuai aturan berdasarkan tugasnya masingmasing. seperti halnya kepala kansilog yang mengamati para pegawai gudang dalam melaksanakan tugas.

Perhitungan adalah teknik pelaksanaan pengawasan yang dilakukan oleh Perum Bulog Kabupaten Bone untuk mengetahui jumlah pangan yang ada di dalam gudang kemudian disesuaikan dengan hasil administrasi. Dalam melakukan perhitungan Sistem Pengawas Internal (SPI) memiliki cara tersendiri dalam menghitung cepat bahan pangan yang ada di gudang Perum Bulog Kabupaten Bone.

Dalam menghitung bahan pangan yang ada di Perum Bulog Kabupaten Bone caranya dengan melihat kunci tumpukan bahan pangan, hal tersebut dilakukan oleh Sistem Pengawas Internal (SPI) Perum Bulog Kabupaten Bone untuk lebih cepat dalam menghitung bahan pangan di gudang. Selain hal tersebut menggunakan kunci dapat menguatkan tumpukan bahan pangan di gudang. Ada dua perhitungan bahan pangan di gudang yang dilakukan oleh Sistem Pengawas Internal (SPI) yaitu pertama, menghitung jumlah bahan pangan yang ada di gudang menggunakan kunci bahan pangan dari samping, belakang dan tinggi lapisannya ke atas kemudian dikalikan kunci lima. Kedua, menghitung isi dalam satu tumpukan berdasarkan hitungan karungnya dan dikalikan berdasarkan kilonya dan kemasannya.

Perum Bulog Kabupaten Bone tidak hanya melakukan perhitungan stok pangan di gudang dan pencapaian target, namun juga melakukan perhitungan dari segi administrasi untuk menghitung hasil penjualan komersil dan perhitungan selisih harga pangan di pasar Bajoe dan Palakka yang merupakan pusat pasar pembelanjaan di daerah Bone. Hal tersebut dilakukan untuk mengetahui terkendalinya pangan yang ada di Perum Bulog Kabupaten Bone. Selain hal tersebut terdapat pula perhitungan hasil penjualan komersil.

Analisis merupakan teknik pelaksanan pengawasan yang dilakukan untuk menentukan kualitas 
Kolaborasi : Jurnal Administrasi Publik, April 2020 Volume 6 Nomor 1

dari hasil pekerjaan di Perum Bulog Kabupaten Bone. Hal tersebut dilakukan untuk mengetahui kepastian terhadap hasil kebenaran dan kekeliruan dalam melaksanakan pekerjaan di Perum Bulog Kabupaten Bone. Beberapa hal yang menggunakan analisis di Perum Bulog Kabupaten Bone menurut penuturan salah satu pegawai bahwa seperti pengamatan kualitas beras, kadar air, dan pencatatan laporan komersil dan stabilitas harga pasar. Dalam menganalisis pangan yang masuk di gudang ada beberapa hal yang diperhatikan seperti kadar air beras harus di bawah 14,00 apabila lebih maka tidak memenuhi standar (TMS) untuk masuk gudang sehingga beras yang ingin diketahui kadar airnya tidak boleh dipegang oleh tangan karena dapat menyerap air pada tangan kemudian diacakacak dan diperiksa sampai tiga kali, selanjutnya menir atau butir patah pada beras diangang sampai 15 kali sampai menirnya maksimal 2 butir kemudian ditimbang, menir atau butir patah yang telah diangang dinamakan broken. Beras yang telah dianalisis kemudian dibuatkan sampel, satu sampel untuk kemitranya dan satu sampel untuk disimpan di gudang.

Namun dalam kenyataan yang ada di lapangan, hal tersebut didapatkan oleh peneliti dengan adanya beras yang diambil dari gudang kemudian dianginkan menggunakan kipas angin di belakang gudang karena beras tersebut tampak basah, maka hal tersebut tidak sesuai dengan kadar air beras yang seharusnya lolos masuk gudang dengan memenuhi standar dengan kadar air yang tidak lebih dari 14,00, namun kenyataannya beras dari gudang tersebut tampak basah untuk dikemas menjadi komersil kemudian dijual ke masyarakat.

Selain menganalisis beras sebelum dimasukkan ke gudang, Perum Bulog Kabupaten Bone juga melakukan analisis harga pasar dan komersil, hal tersebut dilakukan untuk menghindari terjadinya kekeliruan dalam pelaporan administrasi. Analisis yang dilakukan seperti pencatatan harga bahan pangan yang ada di pasar Bajoe dan Palakka. hal tersebut dilakukan 
Kolaborasi : Jurnal Administrasi Publik, April 2020 Volume 6 Nomor 1

setiap hari kecuali hari libur, perminggu dan perbulan untuk dilaporkan kepusat. Selain analisis harga pasar yang dilakukan oleh Perum Bulog Kabupaten Bone juga terdapat analisis komersil yang merupakan program baru Perum Bulog yang melakukan penjualan bahan pangan di masyarakat berdasarkan harga eceran tertentu (Het).

Pelaporan adalah teknik terakhir dalam pelaksanaan pengawasan untuk mengetahui hasil kerja dan terlaksananya kegiatan yang ada di Perum Bulog Kabupaten Bone. Hasil dari laporan yang diterima dari Perum Bulog Kabupaten Bone kemudian diperiksa oleh Sistem Pengawas Internal (SPI) dan dari pusat Perum Bulog Makassar. Pelaporan Perum Bulog Kabupaten Bone diterima oleh Sistem Pengawas Internal (SPI) kemudian setelah terjun langsung ke Perum Bulog Kabupaten Bone Pelaporan tersebut dicocokkan dengan bahan pangan yang ada di gudang, dan setelah mencocokkan pelaporan kemudian Sistem Pengawas Internal (SPI) membuat pelaporan juga untuk distor ke Pusat Perum Bulog Makassar.

Selain pelaporan yang dibuat oleh Sistem Pengawas Internal (SPI), terdapat pula laporan bulanan yang dibuat oleh Perum Bulog Kabupaten Bone mengenai administrasi yang ada di kantor Perum Bulog Kabupaten Bone. Pelaporan yang dilakukan yaitu mengenai kegiatan dan program kerja di Perum bulog Kabupaten Bone serta pelaporan keamanan bahan pangan yang ada di gudang Perum Bulog Kabupaten Bone kemudian dilaporkan kepada Sistem Pengawas Internal (SPI).

Selain pelaporan di gudang terdapat pula pelaporan stabilitas harga pangan di pasar Bajoe dan pasar Palakka yang merupakan pusat pasar pembelanjaan terbesar di kota Bone. petugas gasar Perum Bulog Kabupaten Bone membuat pelaporan pencatatan harga untuk mengetahui kestabilan harga bahan pangan yang ada di pasar, kemudian hasil dari pencatatan harga dikirim ke pusat untuk dilaporkan. Hal tersebut dilakukan oleh Perum Bulog Kabupaten Bone untuk mengetahui selisih harga pangan dan loncatan 
Kolaborasi : Jurnal Administrasi Publik, April 2020 Volume 6 Nomor 1

harga yang ada di pasar Bajoe dan pasar Palakka.

Selain stabilitas harga pasar terdapat pula pelaporan penjualan komersil yang dilakukan oleh perum Bulog Kabupaten Bone, hal tersebut dilakukan untuk mengetahui jumlah penjualan dan bukti penyetoran komersil yang ada di Perum Bulog Kabupaten Bone.

Pelaksanaan pengawasan yang diterapkan di Perum Bulog Kabupaten Bone masih memerlukan banyak perbaikan sehingga tidak terdapat kesalahan dan kekeliruan, terutama pada kualitas pangan yang seharusnya dijaga dan dikendalikan oleh para pegawai di gudang sehingga tidak merusak kepercayaan masyarakat. Teknik pemeriksaan dan analisis di Perum Bulog Kabupaten Bone sebaiknya diaplikasikan dengan baik oleh pegawai di Perum Bulog Kabupaten Bone.

\section{KESIMPULAN}

Berdasarkan hasil penelitian yang ditemukan peneliti maka dapat disimpulkan bahwa pelaksanaaan pengawasan badan urusan logistik (bulog) meliputi : (1) Pemantauan yang dilakukan Perum Blog Kabupaten Bone meliputi pemantauan kondisi bahan pangan dan memastikan keamanan bahan pangan yang ada di setiap gudang, pemantauan terhadap stabilitas harga pasar, dan keamanan harga bahan pangan dan untuk menstabilkan harga pasar. (2) Pemeriksaan dilakukan oleh Sistem pengawas internal (SPI) dan Kepala Kansilog Kabupaten Bone yang dilakukan oleh Perum Bulog Kabupaten Bone mencakup pemeriksaan pada bidang administrasi dan pemeriksaan pada bahan pangan yang ada di gudang. (3) Penilaian yang dilakukan oleh Perum Bulog Kabupaten Bone mencakup penilaian pada nilai gudang dan penilaian target kerja para pegawai Perum Bulog Kabupaten Bone, (4) Wawancara yang dilakukan oleh Perum Bulog Kabupaten Bone mencakup prosedur yang ada digudang Perum Bulog Kabupaten Bone, kemudian wawancara juga dilakukan oleh petugas gasar dengan wawancara masyarakat di pasar bajoe dan pasar palakka mengetahui stabilitas harga pasar, (5) Pengamatan yang ada di 
Kolaborasi : Jurnal Administrasi Publik, April 2020 Volume 6 Nomor 1

Perum Bulog Kabupaten Bone yaitu kesesuaian antara aturan dan pelaksanaan yang ada di lapangan, (6) Perhitungan yang dilakukan oleh Perum Bulog Kabupaten Bone yaitu perhitungan pangan yang ada di gudang, perhitungan pencapaian target pangan yang ada dalam setiap gudang, dan perhitungan selisih harga pasar bajoe dan pasar palakka, (7) Analisis Perum Bulog Kabupaten Bone menganalisis kadar air beras, menir atau butir patah, pencatatan harga bahan pangan yang ada di pasar bajoe dan di pasar palakka, selain itu juga perum bulog juga menganalisis penjualan komersil. Namun dalam hal analisis kadar air beras terlihat tidak begitu maksimal karena beras termasuk dalam tidak memenuhi syarat, (8) Pelaporan yang dilakukan oleh Perum Bulog Kabupaten Bone meliputi laporan bulanan yang distor di Sistem Pengawas Internal (SPI), pelaporan yang dibuat oleh kepala gudang setiap ada kegiatan di gudang, pelaporan pencatatan harga bahan pangan yang ada di pasar bajoe dan pasar palakka, dan pelaporan penjualan komersil.

\section{DAFTAR PUSTAKA}

Antohy, Rober. N dan Vijay Govindarajan. 2008. Sistem Pengendalian Manajemen. Edisi Sebelas. Jakarta: Salembang Empat

Bungin, Burhan. 2011. Penelitian Kualitatif Komunikasi, Ekonomi, Kebijakan Publik Ilmu Sosial Lainnya. Jakarta: Kencana.

Makmur. 2011. Efektivitas kebijakan kelembagaan pengawasan. Bandung: Refika Aditama.

Moleong, Lexy.2014. Metodologi Penelitian Kuantitatif. Bandung: Remaja

Murhaini, Suriansyah, 2014 Manajemen Pengawasan Pemerintahan Daerah. Yogyakarta: Pustaka Pelajar.

Murwaningsih, tri. 2013. Perencanaan dan pengawasan .Surakarta: UNS Press

Rosdayakarya.

Mukarom, zenal dan Muhidin Wijaya Laksana. 2015. Managemen Pelayanan Publik. Bandung : CV pustaka Setia

Sugiyono. 2014. metode penelitian administrasi: Bandung. Alfabeta

Wahyu, setiawan, 2017. Bumn Pangan: Jakarta. Penebar Swadaya 
Kolaborasi : Jurnal Administrasi Publik, April 2020 Volume 6 Nomor 1

Usman, Effendi. 2015. Asas-Asas Manajemen, Jakarta : PT. Raja Grafindo Pera

Torang, Syamsir. 2013. Organisasi Dan Manajemen, Bandung : Alfabeta

Fitria Rahmawati, Hetty. 2007. Peranan pengawasan dalam meningkatkan kedisiplinan kerja pegawai di kantor dan komunikasi kabupaten karanganyar tahun 2007. 